\title{
REINTERPRETING THE DEMOCRATIC ROLES OF THE MEDIA
}

Copyright (c) 2007 Associação Brasileira de Pesquisadores em Jornalismo / SBP Jor
JAMES CURRAN

Goldsmiths College, University of London, England
ABSTRACT

KEY-WORDS
Investigative journalism, according to traditional theory, has the task of exposing the abuses of public officials. Therefore, media has been seen as an institution central to liberal democracy. In this article, I examine examples of the role of media in United Kingdom, in United States of America and in Brazil showing how extensive media coverage in these countries drew attention to police violence. The challenge for all of us is to work out what should be retained from this tradition, and what should be revised or rejected - and to think about the concrete implications of what results from our reappraisal.

In October 2003, the British Broadcasting Corporation (BBC) transmitted an undercover documentary, The Secret Policeman, which exposed racism in the British police force. A hidden camera showed, among other things, a police recruit wearing a Klu Klu Klan hood simulating - for pleasure - the beating up of an Asian. The programme was watched by 5 million people, resulted in six police officers resigning, and led to major reviews of police training and recruitment procedures.

Both the government and the police had attacked the programme before it went out, with the Home Secretary, David Blunkett, declaring it a 'stunt' intended "to create, not report, a story"'. Both were forced to change tack in response to the public outcry caused by the programme's disclosures.individuals refer.

This was an honourable example of a media organisation contributing to the healthy functioning of democracy by exposing abuses within the police force. Yet, it pales into significance by comparison with the best- 
selling book written by the remarkable Brazilian journalist, Caco Barcellos's, exposing in 1992 the activities of the military police in São Paulo. Barcellos calculated that, out of 3200 cases of people officially reported to have resisted arrest over a twenty year period, only 28 survived. Those killed were mostly blacks and people of mixed race. Their extermination reflected an officially sanctioned policy of zero tolerance. The public furore created by his revelations led to important reforms, and a significant reduction of police violence in São Paulo².

During the same period, the American media also drew attention to police violence. They reported that Rodney King, an African-American motorist, had been pulled up for speeding, fled, been apprehended and then repeatedly beaten by three white Los Angeles police officers in front of a sergeant and seventeen other police officers. The event, videotaped by an amateur cameraman, was broadcast numerous times in 1991-2 on American television, and was the subject of extensive newspaper coverage throughout the US ${ }^{3}$. Media investigation revealed that what happened to Rodney King was part of a larger problem. The city of Los Angeles had paid more than $\$ 20$ million between 1986 and 1990 in judgements, settlements and jury verdicts against Los Angeles police officers in over 300 lawsuits involving the excessive use of force. An official enquiry into the police force was initiated, leading to the resignation of the Los Angeles police chief, Daryl Gates. However, the three police officers involved in Rodney King's beating were subsequently acquitted.

Less celebrated but in some ways more impressive was Peter Karl's investigation of the Chicago police in 1983. This took six months to research, aided by three journalism students, and resulted in the five-part series, Beating Justice, transmitted on the Chicago NBC affiliate, Channel 5. It revealed shocking instances of police violence, including the use of an electric cattle iron on a suspect's genitals and down his throat, and the transformation of a once healthy 21-year old man into a quadraplegic, following a ride in a police wagon4. These abuses were committed by a small group of officers, mostly on black people. They were being in effect hushed up, according to Karl, through large out of court settlements paid over a number of years. The series reached 526.000 people, and became a major debating point in a local primary election. The local police chief resigned, and the Office of Professional Standards overseeing the police was reformed ${ }^{5}$. 


\section{Traditional Theory}

All these inspiring examples of investigative journalism conform to the traditional theory of the democratic role of the media, and help to explain its continuing hold on our imagination. This theory proclaims that the first democratic function of the media is to monitor the state, and shield citizens from the tyrannical abuse of its power.

The media's second function is to brief people more generally about what is happening in the world, and enable them to exercise their responsibilities as informed citizens. According to a celebrated Royal Commission report on the press in Britain (with close similarities to the Hutchins Report in the US) ${ }^{6}$ :

'The Press may be judged ....as the chief agency for instructing the public on the main issues of the day.... The democratic form of society demands of its members an active and intelligent participation in the affairs of their community, whether local or national. It assumes that they are sufficiently well informed about the issues of the day to be able to form the broad judgements required by an election, and to maintain between elections the vigilance necessary in those whose governors are their servants and not their masters'?

In addition to providing a faithful record of all that is important, the media should also offer a platform for differing points of view. They should, in the words of the British Royal Commission, 'provide a forum for the expression and exchange of opinion'8. By thus furnishing information and differing opinion, the media facilitate public debate. This leads to the formation of public opinion on the central issues of concern to society.

According to traditional theory, public opinion should influence the formulation and enactment of government policy. The press intercedes to ensure that this happens. The press, proclaimed Thomas Carlyle in a famous passage, is 'a power, a branch of government, with inalienable weight in lawmaking'9. It speaks for the people in the corridors of power, and enables the popular supervision of government.

Adherents of traditional theory sometimes acknowledge that the government also initiates policy and communicates through the press its concerns to the public. This has prompted some to conclude that the press should really be viewed as a two-way channel of communication and influence between government and the governed. However, this position usually argues that the press is - or at least ought to be - mainly on the side of the public in this reciprocal relationship. 


\section{Fossilised Theory}

This model celebrates media empowerment of private citizens. Individuals are protected; briefed; reconstituted as a public body in the form of public opinion; and represented to authority. It thus places the media centre-stage, bathed in a heroic light, as the central intermediary institution of liberal democracy.

This way of thinking continues to be enormously influential. It informs much academic commentary on the democratic functioning of the media ${ }^{10}$. It is reproduced in countless, self-congratulatory press editorials. Indeed, something very close to this traditionalist model is to be found at the heart of a much acclaimed study by the German political philosopher, Jurgen Habermas ${ }^{11}$, and of many publications about the media and the public sphere that it inspired ${ }^{12}$.

Why, then, does this traditional theory seem so pious, so fossilised, so removed from the realities of contemporary life? One reason is that it downplays the role of social groups, political parties, civil society, ideology and globalisation. It seems disconnected from an understanding of how contemporary democracy works.

A second reason is that it is very narrowly concerned with political journalism. It has little to say about fiction and entertainment, indeed about the bulk of the media consumed by most people most of the time. It offers no clue, for example, as to how we should think about the democratic functioning of television soap opera.

Indeed, much of this tradition seems framed by a past that has little relationship to the present. Its antiquated conception of polity as being constituted by the state, private citizens and public opinion derives from late eighteenth century thought ${ }^{13}$. Its preoccupation with political journalism also dates from the eighteenth century when the dominant 'democratic' medium was the elite political press. Its narrow focus on the individual was reinforced in the United States by the idealisation, during the Progressive era, of the 'informed citizen' as the cornerstone of democracy ${ }^{14}$.

We are thus left with a worthy but anachronistic legacy. It has both good ideas and shibboleths. This perhaps account for the increasing uneasiness with which it is viewed in numerous, recent publications ${ }^{15}$. Yet, no new agreed replacement has emerged. The challenge for all of us is to work out what should be retained from this tradition, and what should be revised or rejected - and to think about the concrete implications of what results from our reappraisal. 


\section{Monitoring Of Power}

The element of traditional theory that has weathered best is its conception of the watchdog role of the media. Yet, even here, a case can be made for modest revision.

Traditional accounts argue that journalists should pierce the veil of secrecy surrounding public officials, and expose abuses of their authority. The state should be the main object of press vigilance because it has a monopoly of legitimate violence, and is the 'seat' of power.

While there is some merit in this argument, it can lead to an undue concentration on institutionalised political power, and the neglect of other forms of power - economic, social and cultural - that can also injure or restrict. A better alternative (eloquently advocated in the next chapter) is for the press to maintain critical surveillance of all areas of life.

The traditional focus on the national state also fails to register its decline. The power of national government, especially in economic affairs, has been eroded by the rise of four major players: international regulatory agencies (such as the World Trade Organisation), continental structures and trading arrangements (such as the European Union), global financial markets and transnational corporations. This has given rise to a new 'multilayered system of governance' that is significantly different from the old nation-state system ${ }^{16}$. The traditional watchdog tracking of national government thus fails to grasp that the world of power is changing. As a consequence, it is failing to hold this new system of power to adequate account.

Serious obstacles lie in the way of making the necessary adjustment. With a few exceptions (like CNN and al-Jazeera), the media serve national or local audiences. They are organised in a way appropriate for a simpler age, rather than for the era of globalisation ${ }^{17}$.

The traditional approach also places too much of a load-bearing burden on the journalist. The formative mythology of investigative journalism is that of the intrepid hero or heroine single-handedly ferreting out the truth after months of painstaking investigation. Yet as debunking sociological studies point out, investigative journalism - including the genuinely heroic exposure of the Watergate scandal that brought down President Nixon ${ }^{18}$ - is best understood as 'coalitional journalism' in which journalists work in conjunction with other actors to break and narrate a story ${ }^{19}$. The watchdog role of the press is perhaps best viewed as mediating the investigative resources of a free society - its whistleblowers, dissenting elite members, civil society watchdogs, independent think tanks, and critical researchers - rather than acting as a substitute for them. This makes investigative journalism seem 
more feasible, at a time when budget cuts and changing priorities are often making it more difficult.

\section{Representation Through Partisan Journalism}

More far-reaching reassessment is needed in relation to the rest of traditional theory. Since this appears in slightly different forms, it is worth offering here a fuller exposition of its 'classical' version. Its central claim is that the media's provision of information and debate enables a public consensus to emerge that guides the direction of society. The media enable people to formulate the agreed aims of society, and to secure their implementation by government with the help of 'fourth estate' representation.

This claim is based partly on the assumption that there is an underlying unity of interest in society. Rational debate, underpinned by knowledge and good will, enables this common interest to be identified. The role of the press, therefore, is to provide the necessary knowledge about public affairs, and rational debate about its conduct, to enable citizens to arrive at a common understanding of the public interest. This tradition thus upholds the ideal of comprehensive, objective, dispassionate journalism as the gold standard to which journalists should aspire. It also views with hostility the expansion of media entertainment. This is thought to be a distraction from the serious activity of politics and self-government. Media entertainment is also regarded as being outside the realm of rational debate since it is not evidence-based and bound by the rules of formal logic. While we amuse ourselves, democracy is withering from want of media sprinklers spraying information and reason.

This tradition is founded on a number of false premises. The first of these is its belief in the underlying social harmony of society. Conflict is endemic in politics because there are real differences of interest between social groups about how life chances, public resources and rewards should be distributed in society. Political differences can also express divergent understandings of what constitutes a good society based on irreconcilable social values. Democratic politics is about expressing and managing real conflicts in society. These conflicts cannot be made to disappear through the exercise of reason.

Political conflict can also be healthy. The power to persuade is unevenly distributed in society because the advantaged tend to have greater cultural, social and above all financial resources than the disadvantaged. The former are in a better position to present their 
partial interests as being in the interests of all, and to engineer support for public policies and social arrangements that favour them. In these circumstances, it can be positive for their claims to be questioned, and for the prevailing disposition of rewards to be the subject of aggressive challenge and debate.

The expression of conflict through the media is positive, and should be encouraged for other reasons. It reflects a commitment to free expression, and recognition of the value of dissent, that lies at the heart of free societies ${ }^{20}$. It can lead to better outcomes, informed by an enhanced understanding of alternative claims and a willingness to engage in trade-offs. It can help society to adapt to change. It begets republican virtues: critical independence and distrust of authority. But perhaps a key point to emphasize is that conflict is potentially liberating. People do not instinctively know where their self-interest lies. This knowledge does not emerge pre-formed from social experience or class position. Exposure to contrary argument helps disadvantaged groups to explore critically what best serves them - the first step to advancing their interests. Political partisanship can also release - in certain circumstances ${ }^{21}$ - the life forces of the democratic system, and raise the level of political participation and involvement.

This approach sees partisan journalism as making an important contribution to the functioning of democracy because it puffs air onto the embers of conflict. It offers a way in which reality can be interpreted from the viewpoint of different social and political groups, in place of bland 'spot' reporting of events and topics that are presented in a disconnected and decontextualised way. The strength of partisan journalism is that it adds to the sum of explanation of public affairs. Above all, it makes press representation meaningful. It advances the public presentation of different sectional concerns and solutions, and facilitates the mobilisation of pressure for a political response. However, this presupposes that the partisanship of the engaged press reflects a wide spectrum of group perspectives and interests. It needs to be pluralistic, not skewed in any one direction.

Conventional partisan media, still prominent in Europe, are connected to a political party or social group. There are also numerous advocacy media linked to a particular cause or single-issue organisation. Both forms of adversarial journalism can strengthen the infrastructure of democracy. They can create a space in which members and supporters of an organisation are able to debate with each other, develop new proposals, and sustain a sense of purpose and direction. They can also 
assist democratic organisations to recruit new support, communicate their concerns to a wider public, and mobilise pressure for a response from government. In other words, the representative role of the press should include making civil society more effective and representative.

There are two weak areas of democratic life in need of media rejuvenation. These are the declining party system (still playing a pivotal role in aggregating interests, distributing costs, and defining electoral choices), and the underdevelopment of global civil society. The Internet, with low operating costs and able to facilitate interactive communication, offers a way of mobilising grassroots energy and involvement in the party system, to judge from the 2004 Democratic Party primary elections. The

Internet is also playing a key role in promoting global activism ${ }^{22}$, and in assisting the building of global civil society ${ }^{23}$.

Most partisan and advocacy media operate within certain constraints. Their journalists are, to varying degrees, propagandists working to further a cause, a social group or party. Within the canon of adversarial journalism there also need to be free spirits: columnists, documentary programme makers, political stand-up comics, writers of books, who in individual and idiosyncratic ways seek to make sense of the world. Within this tradition, there is a documentary strand which seeks to 'communicate what it means to be poor among the rich, to be hungry among the wellfed, to be sick among the healthy........ to be unheard, unheard, unheard ...in a society noisy with messages' 24 . Democracy benefits from having journalists in the mould of Studs Terkel, who serve the unorganised and unrepresented.

\section{Conciliation Through Balanced Journalism}

The democratic role of the media thus entails strengthening the organised groupings of civil society and the political system. It benefits from embracing the language of partisanship and difference since these are ways of exciting, involving and mobilising people in the workings of democracy. Yet, the media also need to be involved in limiting conflict, and promoting the search for compromise.

Numerous examples point to the dangers of sectional conflict whether ethnic, religious or class - boiling over into violence, and leading to major atrocities or even programmes of extermination. Banal hatreds can also become embedded within sectional communities, and disable the political process, as in the case of Protestant-dominated Northern Ireland. One mechanistic way of limiting group animosity, liable to result 
in actual physical violence, is to impose limits on free speech through anti-hate law. However, the more positive and constructive approach is to establish within the media system structures and precepts that promote conciliation.

This seems to pose a contradiction. How can the media system simultaneously promote both conflict and conciliation? The answer is that the media are not a single entity. There should be a division of labour in which different sectors of the media have different roles, connect to society in different ways, practice different forms of journalism, and make different contributions to the functioning of the democratic system.

The core media sector - its mass television channels and, in many countries, local monopoly dailies -are the central meeting places of society where different social groups are brought into communion with one another. These core media hold the ring: they should enable divergent viewpoints and interests to be aired in reciprocal debate, and alert mainstream society to the concerns and solutions of minority groups. The norm of journalism practiced by this core sector should be that of balanced journalism, typified by the reporting of different viewpoints expressed by the spokespersons of opposed groups. Its features pages and studio discussions should also provide a forum of debate open to different opinions.

This core sector is also primarily responsible for informing the public. It should offer accurate and intelligent coverage of the news. Crucially, this means reporting not only major events but also the issues and problems that give rise to them. It means examining causes and consequences, not just happenings. As the Hutchins report rightly argued, it entails reporting 'the day's events in a context which gives them meaning'20a.

There are three main reasons why adequate resources and prominence should be given in core media to informing the public. People need to be informed if democracies are to function without a blindfold: people need to know whom and what they are voting for. People need information in order to exert influence: publics kept in ignorance are powerless. Democracies are also devolved systems of power that entail responsibilities as well as rights. This includes an obligation to be informed about major decisions taken with democratic authority. For example, members of a democracy that wages war against another country ought to know, among other things, where that country is, whether the reasons given for war are justified, roughly how many civilians are being killed by their armed forces, and what steps are being taken to benefit the invaded country in the event of an occupation. A democracy that loses the ability to be informed about what is right becomes a threat to the rest of the world. 
If one part of the media system promotes dissent, difference and activism, it is desirable that the core sector is a stabilising force. It should sustain a culture of 'civil democracy' designed to promote conciliation and compromise. This can be best summarised in terms of six norms and values: civility, a way of expressing disagreement that does not seek to delegitimate or marginalize opponents through personal invective; empathy, a desire to comprehend other groups through sympathetic understanding; mutuality, a feeling of being connected to society, and being concerned about the well-being of others; a commitment to the ideal of objectivity, that is the shared pursuit of truth rather cynical advocacy of whatever favours a prior conclusion; a public benefit orientation that recognises that what's-in-it-for-me is not the sole object of public discussion; democratic efficacy, a belief that collective action through the state can achieve worthwhile ends unattainable through individual endeavour alone. In addition, core media should promote social integration through emphasising a shared sense of humanity, a common identity, an inclusive sense of history and collective memory, and shared values.

Core media should also promote conciliation by supporting the rituals and procedures of the democratic system. The most important of these are elections. Dominant media should mobilise people to vote by giving prominence to election campaigns. It is also desirable that media cover elections as significant moments in the collective determination of society by highlighting the political choices involved, rather than as a horse race (or a battle of rival strategists) staged for the entertainment of detached bystanders. Elections that have low turn-outs, and are trivialised, weaken the legitimacy of democratic government, and cease to function as pivotal events in the collective public life of society. It is also important that opposition representatives are adequately reported between elections, both in the interests of maintaining a public dialogue about the direction of society, but also to ensure that 'losers' do not feel disenfranchised.

In short, one central defect of traditional theory is that it ignores the highly differentiated nature of contemporary media systems. Instead of thinking of the media as a unitary institution, it makes more sense to recognise that different media sectors and styles of journalism contribute different things to the democratic process. What these different parts contribute varies, to some extent, between countries, and over time. Thus, the integrative role of the core media sector is being eroded in a number of countries. The growth in the number of television channels is 
subdividing the mass television audience, and weakening the ability of mass television to stage collective debates that bring together divergent groups in an inclusive, conciliatory process - though not to the degree that is often claimed ${ }^{25}$. Some monopoly local dailies are orienting themselves increasingly towards the affluent sections of their local communities, because these attract higher advertising revenue than low income readers ${ }^{26}$. This undermines their ability to stage an inclusive dialogue.

If these trends continue, core media will become less effective. Their work in promoting a political culture of compromise, and in brokering a measure of prior agreement within the public sphere, will have to be shouldered increasingly by the governmental system. This will make democratic government more difficult ${ }^{27}$.

\section{Multidirectional Flows}

The media afford intricate pathways linking the constituent parts of the democratic system. Thus, much prestige journalism takes the form of a horizontal conversation between elites ${ }^{28}$, while radical political periodicals in Europe often provide a bridge between state-funded intellectuals, radical public officials and activated publics. The media provide more generally multiple links between political parties, civil society, sectional publics, the mass public and state institutions. They also articulate major social groups (such as social classes) and sub-cultural groups (such as youth groups) to the system of representation and government. Instead of conceiving of the media in traditional terms as a vertical channel of communication between private citizens and government, it makes more sense to see the media as generating multidirectional flows of communication and influence within the democratic system.

To complicate things further, the media system is also a conduit of communication between different spaces: global, continental, national, regional and local. Thus, the environmental organisation, Greenpeace, used national television systems around the world to mobilise international protest against French nuclear testing in the Pacific, and Shell's proposed dumping of the Brent spar oil platform in the Atlantic, during the mid $1990 s^{29}$.Similarly, beleaguered minority groups - Zapatista dissidents in Mexico $^{30}$ and the Falung Gong in China ${ }^{31}$ - used the Internet and other media to win international sympathy. All three cases illustrate the way in which the media can forge new solidarities across space, in a form that influenced national and international politics. 
The multiple flows of communication and influence generated by the media should facilitate the functioning of the democratic system in certain important ways. These can be summarised as sustaining adequate levels of political information and participation; strengthening civil society and the representative system; facilitating the building of coalitions and the forging of communities of identity; aiding the co-ordination and responsiveness of the democratic system; and sustaining a culture of democracy.

\section{Political Dimensions of Entertainment}

Traditional theory is mistaken in excluding 'non-political' media content from its understanding of democratic processes. Media fiction and entertainment can influence whom people identify with, their understandings of society and where they feel that they fit within it. This can affect profoundly people's politics. Whether people define themselves for example in terms of nationality, locality, ethnicity, gender, religion, generation, class or sexual orientation, and how they articulate these different elements, often has an important bearing on whom they become in 'political' terms.

There is extensive evidence confirming that popular media consumption is bound up with social identity. Thus, teen cultural fashions are often ways of expressing a desire to belong to a particular group, and of excluding others ${ }^{32}$. Sub-cultural style, expressed in music and clothes, can involve a complex negotiation of pressures exerted by parents and peer groups, of competing sources of identity, and even of neighbourhood change and folk memory, in ways that can pull people to the right or left ${ }^{33}$. Online role-playing offers a way in which some explore who they are, and what it is like to be someone else, with implications for identity politics ${ }^{34}$.

Media consumption can also be bound up with how social groups define - and also redefine - themselves, and their relationship to others. Highly stratified media consumption sustained a strong class identity that underpinned historically the political rise of the labour movement ${ }^{35}$. The 'black is beautiful' movement, reflected in ethnic popular culture in the late 1960s and 1970s, fuelled the rejection of a parental culture of 'respectability', and supported more militant political campaigning for equal rights by a new generation ${ }^{36}$. Gay films, novels, journalism and even television fiction also gave expression to a collective, increasingly 
confident 'gay is good' movement that confronted homophobia, and significantly influenced public attitudes and legislation in numerous countries ${ }^{37}$.

Indeed, social groups transmit their values to others partly through the medium of entertainment. Thus, the organised working class has significantly influenced the culture of Europe. This finds expression - and support - in the social democratic values of much western European television soap opera. This is frequently located in working class settings, evokes a strong sense of community, and emphasises solidarity, concern for others, and defence of human rights ${ }^{38}$. Social groups also win visibility or enhanced status through media fiction. The improved position of women, ethnic and sexual minorities during the last thirty years was advanced by changes in their fictional representation ${ }^{39}$.

It is thus difficult to understand why it has become the convention to exclude media entertainment from discussion of the media's democratic role. Politics and media entertainment are plainly interconnected. This becomes even more apparent if conventional understandings of what is 'political' and what constitutes 'self-rule' are questioned.

\section{Self-Regulation}

Self-rule is not confined to elections, and participation in the political life of society. It is not only about making and enforcing law, public administration, delivering public services. It also involves informal self-regulation based public norms. These are the tacit prescriptions, conventions and expectations that guide how we act - whether we stand in line or rush to the front, how we fulfil certain social roles (for example as parent or child), what we feel is appropriate behaviour in myriad situations. These norms are, in a broad sense, collectively arrived at, maintained and enforced. They are acquired through early socialisation, internalised, and supported through social interaction. They are also subject to periodic revision, and can weaken or strengthen over time.

The media are bound up with norm enforcement. Thus, a whole genre of popular content in television, magazines and newspapers (often linked to the reporting of court cases) is about moral and social transgression ${ }^{40}$. It regularly makes distinctions between good and bad, and establishes guidelines about what is acceptable and unacceptable behaviour, through concrete example. For instance, the Daily Mail (a British national newspaper with over two million circulation) devoted a 
two-page article in 2003 to a hitherto unknown woman, Kim Marsham, under the banner headline 'Is This Britain's Most Selfish Mother?'. Kim Marsham, it was revealed, had gone on a one-week foreign holiday with her lover leaving her five young children at home ${ }^{41}$. She had casually left a note asking her neighbour to take care of her children. The neighbour proved to be away at the time, and Kim Marsham's distraught children were taken into temporary care by the local council.

The Daily Mail news report condemned the mother for her 'appalling moral and familial neglect'. It also quoted comments about Kim Marsham from her neighbours, former lovers and so-called 'friends' which vividly conveyed an impression of an immoral, feckless woman. Kim Marsham, it emerged, had had six children by four men. 'Utterly lacking in any sense of self responsibility', according to the report, 'she lives on benefits and takes handouts from the State as her due. She has repeatedly got herself pregnant in the most desperate circumstances.' Readers' moral indignation were skilfully engendered through the contrast drawn between the children's tear-stained, 'terrifying and bewildering ordeal' and Kim Marsham's pleasure-seeking irresponsibility captured by a large photograph of her looking relaxed and happy on holiday with her boyfriend in Gran Canaria, and by an accumulation of telling detail ('dining on steak and chips every night' on holiday).

Kim Marsham was placed in the symbolic equivalent of the stocks in which abuse - rather than rotten food - was thrown at her. Yet if some popular media enforce public norms through rituals of degradation, others engage in discussion. Television talk shows like Kilroy and Trisha in Britain or Oprah Winfrey in the United States have made an impact partly because they allow 'transgressors' to answer back, and enable the studio audience to join in. It easy to intuitively guess, for example, how differently Kim Marsham might have fared in these more democratic fora. She might have pleaded mitigating circumstance (and tacitly upheld the norm of parental duty): she was a good mother, under stress, who thought her neighbour was going to help out. Alternatively, she might have contested the application of the norm: don't absent fathers have a duty of care, too?. Or, more improbably, she could have defied the norm of parental duty, saying that pleasure came first.

Confessional talk shows thus allow public norms to be evaluated through public discussion. They make transparent, through condensed, choreographed melodramatic programmes, a process that takes place all the time through the media: the collective examination, revision, strengthening or weakening of norms through public debate. Only this 
dialogue is dispersed through numerous programmes, films and other output, and takes place over time. Sometimes it is easy to spot because it flares up into a 'culture war', when one sub-cultural group launches an effective attack on an established set of norms, prompting others to counter-attack. There is a long history of normative conflict between social libertarians and fundamentalist Christians, between feminists and traditionalists, and indeed between representatives of different generations, in which opposed groups vie for popular support. These contests are mediated through television fiction, films and consumer journalism ${ }^{42}$, not simply in the political arena.

Media content that is often attacked as a diversion from the serious business of politics and the obligations of public life - 'soft' journalism, 'freak' talk shows, 'formulaic' fiction - can thus be viewed as being part of the public conversation that guides an informal system of 'self-rule' based on public norms. It is part of the way in which society talks about its common social processes and the rules that govern these. It is also an important way in which social norms are challenged and modified, enabling society to adapt and change. The central themes of normative debate conducted through fiction can also influence the formal world of politics - its discourses, policies, laws, even understandings of what politics should be about.

The logic of this reassessment points therefore to the need to include entertainment in our understanding of the democratic role of the media. Broadly, the same arguments that were marshalled in relation to journalism apply also to non-factual media content. It is desirable that major subcultural groups have the communications resources necessary to explore and formulate their concerns, and communicate these to others; and that these concerns are addressed and debated by the wider society through mass media. The equivalent of a culture of civil democracy outlined earlier should also inform this wider debate. One of its central features is that 'other' groups should be portrayed with understanding rather than malignant contempt. The humanistic argument of the Hutchins Report, written over half a century ago, is especially applicable in the contemporary context of growing tension between Islam and the Christian west:

'The truth about any social group, though it should not exclude its weaknesses and vices, includes also recognition of its values, its aspirations, and its common humanity. ......If people are exposed to the inner truth of the life of a particular group, they will gradually build up respect for and understanding of it'43. 
But while non-factual media fulfil a democratic role, they do not provide a substitute for political debate. Most important decisions faced by society, and most important social transformations, involve action in some form by the state. The improvements in the position of women that have taken place in the last forty years, for example, have come about not only through changes in the economy and gender norms but also through equal rights legislation. Given the continuing importance of the state in the life of all modern societies, there needs to be a way of holding it to account and harnessing its power to the benefit of society. This requires not only periodic elections but also a democratic infrastructure and an informed and participant public with the knowledge and resources needed to exercise effective control. In the succinct words of the American political theorist, Alexander Meiklejohn: 'self-government is a nonsense unless the "self" which governs is able and determined to make its will effective' ${ }^{\prime 4}$.

The practice of politics also involves the transfer of knowledge to the public domain, to be debated and evaluated in democratic forum. This requires appropriate spaces in which relevant information can be evaluated. The explicitly political arenas of media debate - news reports, studio discussions, 'op-ed' features - provide more suitable contexts than television soap opera for debating, say, tax and spend options. They allow people to think about alternatives, trade-offs and consequences, as distinct from engaging in a debate about social values expressed through the interactions of actors in a drama. A diet based exclusively on entertainment - even high protein entertainment that allows for open dialogue and arresting insight - produces an anorexic and anaemic democracy.

\section{Tension Between Market and Democracy}

The question - what does democracy require? - is answered by some with stark simplicity: only free market media. By anchoring the media to the market, it is argued, the media become free of government and answerable to the people. Only in these circumstances can the media fulfil their democratic purpose.

Any form of public intervention (apart from 'light touch' media laws protecting human rights), however well intentioned, subverts the democratic functioning of the media. 'I cannot envisage', writes American journalism professor, Carl Stepp 'any kind of content regulation, however indirect, that wouldn't project government into the position of favouring 
or disfavouring some views and information over others. Even so-called structural steps aimed at opening channels for freer expression would post government in the intolerable role of super-gatekeeper' ${ }^{\prime 5}$. This position rules out - as a matter of adamantine principle - nearly all progressive reforms of the media attempted around the world during the twentieth century.

This stance is potentially bolstered by other considerations. New communications technology - in particular, cable, satellite and the Internet - has increased the diversity of the media, and reversed in some sectors the trend towards increased concentration of media ownership ${ }^{46}$. It is also argued eloquently that highly selective scanning of the news in order to pick out what is relevant and important makes for a more rational use of time, when private pleasure beckons, than becoming a news junkie ${ }^{47}$. The primary role of popular media is therefore to sound a burglar alarm if something goes wrong ${ }^{48}$. These last two arguments thus scale down both what democracy needs, and what it requires from the media ${ }^{49}$. They can be read as a sophisticated accommodation to what others view as cumulative defects in the American democratic and media systems ${ }^{50}$.

Yet, whatever view is taken, a tension exists between the needs of democracy and the needs of the market. This tension is being resolved increasingly by democracy being shortchanged. Take for example the role of the media as a monitor of state power that most people agree is one of the media's democratic functions. It is an expensive, time-consuming business often attracting only a minority audience. It may be desirable but it is not very profitable. This has caused some increasingly market-driven organisations either to cut back their investigative journalism, or attempt to popularise it by focusing on crime and what affects people's pockets (such as crooked car mechanics and plumbers). The latter strategy was pursued by the main commercial television channel in Britain when, following the 1990 Broadcasting Act, it became subject to less public service regulation. A 'new broom' Director of Programmes, Paul Jackson, warned in 1992 that if the leading investigative journalism weekly programme, World in Action, were to 'uncover three more serious miscarriages of justice while delivering an audience of three, four or five million, I would cut it. It isn't part of the ITV system to get people out of jail'51. The series was duly cut, and there was between 1989 and 1998 a dramatic reduction of ITV investigative journalism into the abuse of state power ${ }^{52}$.

There is general agreement also that the media should serve democracy by carrying information about public affairs. However, this information has only a minority market. The solution to this problem in Britain is to ration: 
popular national papers (accounting for three out of four sales) devote less than 20 per cent of their editorial content to public affairs ${ }^{53}$. The solution chosen by American local TV in the 1990s was to give prominence to crime because it was both cheap and popular (particularly if it included human interest drama, car chase action or contained ingredients that aroused fear or indignation). However, the effect of this sensible market strategy was to misinform. Large nightly doses of local crime led growing numbers of people to think that crime was America's biggest problem, even at a time when crime was actually falling ${ }^{54}$.It also fostered simplified or mistaken perceptions of crime that encouraged racial animosity ${ }^{55}$.

A strong case can be made in principle that partisanship extends the diversity of the media, and contributes to the functioning of democracy. However markets, distorted by high entry costs and oligopoly, can result in unrepresentative leadership of the media. This can cause media to be skewed strongly to the right of their audiences, as is the case with the newspaper press in a number of Latin American, European and Asian countries ${ }^{56}$.Partisan media concentration can also lead to a fundamental distortion of democracy, as in Italy where a media mogul dominating commercial television - with no prior experience of public office - was catapulted into the position of heading the government ${ }^{57}$.

\section{American Dilemma}

Two broad strategies have been adopted to tackle these problems ${ }^{58}$. One is the social market approach: state support of minority media, typified by selective press and film subsidy schemes introduced in numerous countries, in order to sustain media diversity and collective self-expression. The other is the public service approach: encouraging television and radio to serve democracy - by informing the public, adhering to norms of balanced journalism, aiming for quality - through public regulation or ownership. These two approaches are part of mainstream politics in Europe, supported by Christian Democrat and Social Democrat parties alike. The public service approach also enjoys strong support in some democratic countries in Asia, Africa, Australia and Latin America.

However, what seems unexceptionable in many parts of the globe is deeply contentious in the United States. Instead, the US has taken a different path: the nurturing of a public interest culture among American media professionals in a way that bypasses the state. This was the social responsibility strategy promulgated by the celebrated Hutchins Report. Although it generated conventions criticised by radical American academics 
for promoting Establishment journalism beholden to power-holders ${ }^{59}$, it eased the conflict between market and democracy, and made on balance for better journalism ${ }^{60}$.

However, the Hutchins 'fix' is becoming unfixed. The professional power and autonomy of American media staff is weakening, and its public service culture is under siege. This puts American democrats (with a small ' $d$ ') in a dilemma. Policies pursued around the world cannot be contemplated in America (partly because of the failure of its PBS system); yet the American, social responsibility strategy is in trouble. It seems likely to be in still greater trouble in the future because of the changes that are taking place in American media.

What is the solution? Finding one matters not only for Americans. The quality of American democracy and American media is now a global concern because the United States dominates the world.

\section{NOTES}

1 John Plunkett. 'It wasn't a stunt', Guardian, October 27, 2003

2 Silvio Waisbord. Watchdog Journalism in South America. New York: Columbia University Press, 2000, p. 41-42.

3 Jeffrey Alexander and Ronald. N. Jacobs. 'Mass communication, ritual and civil society' in Tamar Liebes and James Curran (eds.) Media, Ritual and Identity. London: Routledge, 1998, p. 35.

4 David Protess, Fay Cook, Jack Doppelt, James Ettema, Margaret Cordon, Donna Leff and Peter Miller. The Journalism of Outrage. New York: Guilford Press, 1991, pp. 119-120.

5 Ibid, pp.126-133.

6 Robert Leigh (ed.). A Free and Responsible Press. Chicago: University of Chicago Press, 1947 [Hutchins Report].

7 Royal Commission on the Press 1947-1949 Report, HMSO (Cmd. 7700), London, 1949, pp.100-101.

8 Ibid, p. 101. 
9 Thomas Carlyle. On Heroes, Hero-Worship and the Heroic in History. London: Chapman and Hall, 1907, p.164.

10 Judith Lichtenburg (ed.) Democracy and the Mass Media. Cambridge: Cambridge University Press, 1990; Brian McNair. An Introduction to Political Communication. 3rd edition, London: Routledge, 2003, chapter 2.

11 Jurgen Habermas. The Structural Transformation of the Public Sphere. Cambridge: Polity, 1989 [in German: 1962].

12 Paddy Scannell. 'Public service broadcasting and modern public life'. In: Media, Culture and Society, 11 (2), 1989; Nicholas Garnham. Capitalism and Communication, London: Sage, 1990; and Craig Calhoun (ed.) Habermas and the Public Sphere. Cambridge, Mass: MIT Press, 1992.

13 Helen Barker. Newspapers, Politics and Public Opinion in Late Eighteenth Century, Oxford: Oxford University Press, 1998. For a succinct, schematic account of early free press theory, see John Keane. The Media and Democracy. Cambridge: Polity, 1991.

14 Michael Schudson. The Good Citizen. New York: Free Press, 1998.

15 Helpful publications which question implicitly or explicitly key tenets of traditional theory, sometimes from opposed positions, include: $\mathrm{C}$. Edwin Baker. Media, Markets and Democracy. Cambridge: Cambridge University Press, 2002; W. Lance Bennett and Robert Entman (eds.) Mediated Politics. Cambridge: Cambridge University Press, 2001; Timothy Cook. Governing With the News. Chicago: Chicago University Press, 1998; James Curran. Media and Power. London: Routledge, 2002; Herbert Gans. Democracy and the News. Oxford: Oxford University Press, 2003; Jurgen Habermas. Between Facts and Norms. Cambridge: Polity, 1996; Robert Hackett and Yuezhi Zhao, Sustaining Democracy? Toronto: Garamond Press, 1998; John Keane. The Media and Democracy. Cambridge: Polity, 1991; Robert McChesney. Rich Media, Poor Democracy. Urbana: University of Illinois Press, 1999; Thomas Meyer (with Lew Hinchman) Media Democracy. Cambridge: Polity, 2002; Michael Schudson. The Good Citizen, New York: Free Press, 1998; Michael Schudson. The Sociology of News, New York: Norton, 2003; John Street. Mass Media, Politics and Democracy. Palgrave: Basingstoke, 2001; John Zaller. 'A New Standard of News Quality: Burglar Alarms for the Monitorial Citizen', In Political Communication, 20, 2003.

16 Standard introductions debating the nature and significance of this shift in the system of power, from different perspectives, are Leslie Sklair. 
Globalization, $3^{\text {rd }}$ edition, Oxford: Oxford University Press; David Held et al. Clobal Transformations. Cambridge: Polity, 1999; David Held and Anthony McGrew (eds.) The Global Transformations Reader. $2^{\text {nd }}$ edition, Cambridge:Polity, 2003; Frank Lechner and John Boli (eds.) The Globalization Reader $2^{\text {nd }}$ edition, Oxford: Blackwell, 2004.

17 See chapter 3.

18 Gladys Lang and Kurt Lang. The Battle for Public Opinion. New York: Columbia University Press, 1983.

19 Protess et al., op. cit., 1991.

20 Thus the Fundamental Law (Article 39) of Saudi Arabia states 'publication of anything that might lead to internal rifts ...... is forbidden'(cited Street, op cit., 2001, p.250), whereas the Conservative British government proclaimed, by contrast, 'a free and diverse media ......promote the culture of dissent which any healthy democracy must have' (Media Ownership: The Government's Proposals, HMSO, 1995, cm 2872, p.3).

20a Leigh, op. cit. [Hutchins Report], 1947, p.20.

21 Recurring, negative adversarial comment can clearly diminish political involvement. But what Thomas Patterson calls the politics of antipolitics' of American news media (T. Patterson. The Vanishing Voter. New York: Vintage,2003) does not correspond to committed forms of media partisanship.

22 Graham. Meikle. Future Active. New York: Routledge, 2002; W. Lance Bennett. 'New Media Power: The Internet and Global Activism' in Nick Couldry and James Curran (eds.) Contesting Media Power. Lanham: Rowman and Littlefield, 2003.

23 James Curran. 'Clobal Journalism: A Case Study of the Internet' in Couldry and Curran, op. cit., 2003.

24 Malcolm Maclean cited in 'Journalism, Advocacy and a Communication Model for Democracy' in M. Raboy and P. Bruck (eds.) Communication for and Against Democracy. Montreal: Black Rose Books, p. 170.

25 For comparative viewing figures, see Curran, op. cit., 2003, table 7.2, p. 190. 
26 C. Edwin Baker. Advertising and a Democratic Press. Princeton, NJ: Princeton University Press, 1994.

27 A standard strategy for building consensus pursued in a number of countries is to develop liberal corporatist networks of consultation and conciliation brokered by the state.

28 For a good illustration of this in relation to business journalism, see Aeron Davis.Public Relations Democracy. Manchester: Manchester University Press, 2003.

29 Paul Manning. News and News Sources. London: Sage, 2001.

30 Manuel Castells. The Power of Identity. Oxford: Blackwell, 1996.

31 Yuezhi Zhao. 'Falun Gong, Identity, and the Struggle over Meaning Inside and Outside China', in Couldry and Curran, op. cit., 2003.

32 S. Thornton and K. Gelder (eds.) The Subcultures Reader. London: Routledge, 1996.

33 This is the central insight of the Birmingham Centre youth studies, the best example of which is Dick Hebdige. Subculture. London: Routledge, 1979.

34 Martin Lister et al. New Media. London: Routledge,2003; Mark Poster, What's the Matter With the Internet. Minneapolis: University of Minnnesota Press, 2001.

35 Ross McKibbin. Classes and Cultures. Oxford: Oxford University Press, 1998.

36 Paul Gilroy. There Ain't No Jack in the Union Jack. London: Routledge, 2002.

37 Larry Gross. Up from Invisibility. New York: Columbia University Press, 2002; Jeremy Weeks. Sex, Politics and Society, $2^{\text {nd }}$ edition, Harlow: Longman, 1989.

38 Hugh O'Donnell. Good Times, Bad Times: Soap Operas and Society in Western Europe. London: Leicester University Press, 1999. 
39 Gross, op. cit., 2002; Myra Macdonald. Representing Women. London: Arnold, 1995; Terry Sanderson. Mediawatch. London: Cassell, 1995; Robert Ferguson. Representing 'Race'. London: Arnold, 1998.

40 A good study of this, based on Canadian media, is R. Ericson, P. Baranek and J. Chan. Visualizing Deviance. Milton Keynes: Open University Press, 1987.

41 Daily Mail, 8 March, 2003.

42 For examples of studies of feminist influence on popular media, see among others Julie d'Acci. Defining Women. University of North Carolina, Chapel Hill, 1994 and Anna Gough-Yates. Understanding Women's Magazines. London: Routledge, 2003.

43 Leigh, op. cit., 1947, p. 27.

44 Alexander Meiklejohn. 'The Rulers and the Ruled' in Haigh Bosmajian (ed.) The Principles and Practice of Freedom of Speech, $2^{\text {nd }}$ edition. Lanham: University Press of America, 1983, p. 276.

45 Carl Stepp. 'Access in a Post-Social Responsibility Age' in Judith Lichtenberg (ed.) Democracy and the Mass Media. Cambridge: Cambridge University Press.

46 This argument is especially well marshalled in Benjamin Compaine and Douglas Comery. Who Owns the Media? $3^{\text {rd }}$ edition. Mahwah: Lawrence Erlbaum, 2000.

47 Schudson, op.cit., 1998.

48 Zaller, op.cit., 2003.

49 Rival theories of democracy are discussed more fully in chapter 2.

50 Thomas Patterson. Out of Order. New York: Knopf, 1993; Patterson, op. cit., 2003; John McManus. Market-Driven Journalism. Sage, Thousand Oaks, 1994; James Hamilton. All the News That's Fit to Sell. Princeton: Princeton University Press, 2004, among others.

51 Cited in Steven Barnett and Andrew Curry. The Battle for the BBC. London: Aurum, 1994, p.249. 
52 Steven Barnett and Emily Seymour. A Shrinking Iceberg Moving South. London: Campaign for Quality Television,1999, p.16.

53 James Curran and Jean Seaton. Power Without Responsibility, $6^{\text {th }}$ edition. London: Routledge, 2003; S.Mclachlan and P.Golding. 'Tabloidization in the British Press: A Quantitative Investigation into Changes in British Newspapers, 1952-1997' in Colin Sparks and John Tulloch (eds.) Tabloid Tales. Lanham: Rowman and Littlefield, 2000.

54 Thomas Patterson. 'The Search for a Standard: Markets and Media'. In Political Communication, 20, 2003.

55 Franklin Gilliam, Shanto Iyengar, Adam Simon and Oliver Wright. 'Crime in Black and White: The Violent, Scary World of Local News' and Robert Entman, 'Modern Racism and Images of Blacks in Local Television News', both in Shanto lyengar and Richard Reeves (eds.) Do The Media Govern? Sage, Thousand Oaks, 1997.

56 Mary Kelly, Gianpietro Mazzoleni and Denis McQuail. The Media In Europe. London: Sage, 2004; James Curran and Myung-Jin Park (eds.) DeWesternizing Media Studies. London: Routledge, 2000; Waisbord, op.cit., 2000.

57 Paul Ginsborg. Italy and its Discontents. Allen Lane, Harmondsworth, 2001.

58 See chapter 1. For an outline of an 'optimal' model of a democratic media system, drawing on the 'third way' tradition of European media policy, see Curran, op. cit., 2002.

59 For example, Gaye Tuchman. Making News. New York: Free Press, 1978 and Mark Fishman. Manufacturing the News. Austin: University Texas Press, 1980.

60 For an historical audit, see chapter 4

James Curran is professor of Communications at Coldsmiths College in University of London and External Editor of the Media and the Net Themes at OpenDemocracy. He is currently the United Kingdom representative on the European Comission Committee promoting research on broadcasting in Europe. 